\title{
4. Papua Coming of Age: The Cycle of Man's Civilisation and Two Other Papuan Histories
}

\author{
Jaap Timmer
}

In Maurice Halbwachs's Les cadres sociaux de la mémoire (1952) and La topographie légendaire des évangiles en terre sainte: Etude de mémoire collective (1941) (published together in English as On Collective Memory in 1992) we learn that it is through membership of a social group that people are able to acquire, to localise and to recall memories. Halbwachs's theory of the social construction of memory demonstrates that 'society tends to erase from its memory everything which could separate individuals' (1992: 182-183). It is in the interaction between the individual and society that individual memories are reshaped and reconstructed. Along these lines, Michael Jackson points out that it is in the process of personal memories becoming collectivised and historicised that they cease to be properties of individual minds and enter into intersubjectivity. As such the line between immediate and interpreted experience effectively disappears' (1998: 140). Or, as Paul Connerton, in his reflection on Halbwachs' theory, explains:

What binds together recent memories is not the fact that they are contiguous in time but rather the fact that they form part of a whole ensemble of thoughts common to a group, to the groups with which we are in a relationship at present or have been in some connection in the recent past. When we wish to evoke such memories it is enough if we direct our attention to the prevailing interest of the group and follow the course of reflection customary to it. Exactly the same applies when we want to recall more distant memories. To evoke such memories, it is enough, once again, to direct our attention to the recollections which occupy a primary place in the thoughts of the group (1989: 36-37).

Histories, then, are narratives possessed of authority for which claims are made not only to the status of truth, 'but what is more, to the status of paradigmatic truth' (Lincoln 1989: 24). Bruce Lincoln (1989) presents compelling reasons 'to classify narratives not by their content but by the claims that are made by their narrators and the way in which those claims are received by their audience(s)' (p. 24). In his classification of narratives that includes fables (having no truthclaims at all), legends (making truth-claims but lacking credibility), history (enjoying credibility amid its audience), and, the most crucial one is myth (both 
credible and having authority). On the authority of myth, Lincoln, following Malinowski and Geertz, argues that it lies in the status of the myth's claim to paradigmatic truth:

In this sense the authority of myth is somewhat akin of that of charters, models, templates, and blueprints, but one can go beyond this formulation and recognize that it is also (and perhaps more important) akin to that of revolutionary slogans and ancestral invocations, in that through the recitation of myth one may effectively mobilize a social grouping. Thus, myth is not just a coding device in which important information is conveyed, on the basis of which of which actors can then construct society. It is also a discursive act through which actors evoke the sentiments out of which society is actively constructed (ibid.: 24-25).

Following Lincoln's view on myth (see White 1987), I will illuminate the paradigmatic truths and related moral components in three historical narratives authored by Papuans about the past, to show how they, in different but overlapping ways, construct the idea that Papua is coming of age in what they claim to be a genuinely historical account. They are vernacular logics of reality and they are performative historicities - much of the meaning that they give to the past is made in the act of their communication to specific audiences (Dening 1991, see Rutherford 2012). This means that they have to be understood in the context in which they are produced. Consequently the analysis below gives prominence to the question whose historicity and whose criteria for truth? (see Ballard 2014: 101).

The phrase 'coming of age' was used by many Papuans with whom I spoke during my visits to Papua since the mid-1990s. Perhaps most explicitly, Albert, in a narrative I cite below, used it to describe Papua as maturing ('menjadi dewasa'), as moving up the ladder of civilisation, and becoming an independent nation. With respect to the latter he would say 'menjadi Papua'. With the phrase coming of age, then, I try to capture both the conditions under which the historicities are produced and what they convey about people's understanding of oneself and Papua as an identity and a nation. In broad terms, I will conclude that the three historicities suggest that Papua is seen as being on the verge of establishing itself as a sovereign nation but that there are obstacles along the way. The essence, the paradigmatic truth, for getting to sovereignty is in place and is exempt from the law of change. The historical narratives bring to the fore that essential elements of Papua's sovereignty are given by virtue of genealogical connection, largely independent of the situational contexts of human activity and human relationships. This illustrates the extent to which Western genealogical models have shaped Papuan historicity, foremost through particular ways of reading the Bible but also through familiarity with Indonesian national history production and modern state genealogy. 
It is important to realise that the three Papuan histories do not surface in a democratic environment that provides sufficient public space for debate. There are contests over natural resources and economic and political power struggles, and frictions between different ethnicities, religion, and immigrants and locals (Timmer 2007a). Alternative histories emerging from Papua are seen as controversial and subversive by Jakarta. The banning of books like Benny Giay's (2006) account of the abduction and murder of Theys Eluay in 2001 is just one example to illustrate that history writing in Papua can be a dangerous business and this has been the case since the Indonesian government began to rule the territory in the early 1960s. In such conditions, as Talal Asad points out for the concept of orthodox Islam,

the process of determining orthodoxy in conditions of change and contest includes attempts at achieving discursive coherence, at representing the present within an authoritative narrative that includes positive evaluations of past events and persons (1993: 210).

The first narrative is entitled the Cycle of Man's Civilisation (Siklus Peradaban Manusia), which sketches the development of civilisation moving cyclically, not with a teleological goal but propelled by man's inclination to seek completion, because of man's inescapable need for 'the perfect' (yang sempurna). According to this history the people of Papua are authentic, pure, indigenous and not to be classified as 'backward' (terbalakang) and 'primitive' (primitip) by the Indonesian state. The second story traces a genealogical connection between Papua and Java, linking Papua's past to Javanese Kingdoms that are key to Indonesian nationalism. It suggests that original cultural traits from that past are transmitted across generations and provide status to the Onim people of the Southwest Bird's Head of Papua. The third narrative is Basic Guidelines, Don Flassy's (1999) Constitution for West Papua that through finding the essence of Papuan souls in terms of one soul, one nation - mimicking Indonesian national narrative - seeks to unite Papuans in one nation (see Timmer 2013).

The regional focus of this paper is the Bird's Head (Kepala Burung) Peninsula that is well known as the borderland between New Guinea and the Moluccas, where the influences of the sultanates of the North Moluccas have left countless marks and where the first missionaries, C.W. Ottow and J.G. Geissler landed in 1855 (on Mansinam Island). ${ }^{1}$ From a cartographic and local millenarian perspective, the

1 Generally not cited by Papuans, Thomas Forrest of the British East India Company established friendly relationships with people in the Dorei Bay in 1755, and about two decades later Lieutenant John Hayes built Fort Coronation there and renamed the bay Restoration Bay but the British settlement failed after one year. Also more prominent in European historiography than in local histories is John McCluer who, while surveying the coastline for the British East India Company, found all the survivors in Fort Coronation ill. In the mid-19th century, the British naturalist Alfred Wallace spent nearly six months at Dorei Bay in 1858. A few decades later, Count von Rosenberg visited the village of Andai (in 1869) and the Italian naturalists Luigi d'Albertis and Odoardo Beccari did research in the area in 1873 (Gash and Whittaker 1975: 20-23). 
local Reverend Leonardus Jenbise (who is currently a lecturer in a Theological College in Jayapura) portrays the Bird's Head as the upper part that may pull the whole island towards becoming fully established as an independent nation. In the preface to the proceedings of the 1997 Irian Jaya Studies conference in Leiden, Rev. Jenbise is quoted as commenting on the importance of the Bird's Head Peninsula as follows: 'the head must be raised before the bird can fly' (Miedema et al. 1998: xi). Similarly suggesting that Papua is coming of age but with biblical allusions, Flassy writes in Basic Guidelines that 'after chucking The Head of the Bird's Like Island, then the whole body on to the tail shined by the Love of Jesus Christ, from Sorong to Samarai' (Flassy 1999: 7). ${ }^{2}$

\section{Redistributing the cards}

My reading of the three narratives shows that what these particular views of the past or histories do to people's understanding of current events is a kind of stilling of the tumult of different understandings and motives during past events. In a reflection on this European experience of history, James Scott observes that

what 'history' does to our understanding of events is akin to what a television broadcast does to our understanding of a basketball or ice hockey game. The camera is placed above and outside the plane of action, rather like a helicopter hovering above the action. The effect of this bird's-eye view is to distance the viewer from the play and apparently slow it down. Even then, lest the viewer miss a crucial shot or pass, actual slow motion is used to further slow the action and allow the viewer to see it in detail again and again. Combined, the bird's-eyeperspective and slow motion make the player's moves seem deceptively easy to viewers, who might fantasize mastering such moves themselves. Alas, no actual player ever experiences the actual game from a helicopter or in slow motion. And when, rarely, the camera is placed at floor level and close to the action in real time, one finally appreciates the blinding speed and complexity of the game as the players experience it; the brief fantasy is instantly dispelled (2012: 136).

\footnotetext{
2 Samarai is a small island offshore the easternmost tip of Papua New Guinea. Because of easy access by boats it was one of the first places where European traders settled. The bird-like shape of the island as evoked by modern cartography has of course a longer history among Europeans. For example, in The Human Aviary (Holton and Read 1971), Kenneth E. Read writes that New Guinea is 'like a prehistoric mother bird marshaling and fledgling flock that spreads behind it to the boundary of Polynesia. Its great head points toward its Asian homeland, and in the early morning, as it stirs beneath the covers of its clouds, the air seems to be filled with its rumination on the themes of man and time. It existed long before man found protection under its rainbow plumage' (p. 7).
} 
Indeed, all histories are flat as they erase contingency or rather simplify certain contingencies to highlight events and connections that are of contemporary importance to those who construct the narratives. What it does to their understanding is akin to what Scott describes. Scott's thesis is that the condensation of history is the result of 'our desire for clean narratives, and the need for elites and organizations to project an image of control and purpose' (2012: 141). Papuan desire for narratives about the past is also about control and purpose, and the causations apparent in the three historiographies are meaningful as sinews of divine design that instead of conspiring to convey a false image are part of a quest for authenticity to reveal the true character and spirit of the Papuan people and their nation.

This is what makes them different from histories written by foreign observers. For example, the recent histories produced by Dirk Vlasblom (2004) and Pieter Drooglever (2005) are impressive studies of key events in Papua. Vlasblom's history of Papua is a thoroughly studied account of social, cultural and political development in Papua (see Timmer 2005). Drooglever focuses on the issue of decolonisation and the 1969 plebiscite known as the Act of Free Choice (Penentuan Pendapat Rakyat, PEPERA), during which a carefully selected and limited number of Papuans, allegedly representing the voice of local groups, voted in favour of relinquishing sovereignty in favour of Indonesian citizenship (Timmer 2007b: 1102).

Both Vlasblom and Drooglever undertook these studies in response to the Second Congress held in Papua in May-June 2000. This congress followed a first congress, organised by the so-called Independent Committee in October 1961 when the region was still a Dutch overseas territory and the administration in Hollandia (now Jayapura) was frenziedly preparing Papuans for selfdetermination to comply with demands of the United Nations. The First Congress made four national declarations. They declared the Morning Star flag to be the national symbol, declared the national anthem to be Hai Tanahku Papua ('Papua My Country'), declared the name 'West Papua' for the independent state and declared the name 'Papuans' for its people. Two months later, on 1 December 1961, the Morning Star flag was raised alongside the flag of the Kingdom of the Netherlands and Hai Tanahku Papua was sung after the Dutch Wilhelmus anthem in front of the building of the New Guinea Council that was inaugurated by Governor P.J. Platteel earlier that year. The official recognition of these names and symbols for a Papuan state by the Netherlands government has since been explained by many as the initiation of the Papuan nation.

During the Second Congress many Papuans expressed the need to meluruskan sejarah ('straighten history') or an intervention in Indonesian history writing. Papuans see that Indonesia's representation of Papua limits their history to a nation-building narrative that fails to account for the facts of such events as 
the Act of Free Choice, which for many features prominently as the epitome of the denial of sovereignty to Papuans (Saltford 2002; Drooglever 2005). Partly trying to answer Papuan demands, the Netherlands government commissioned Drooglever to study the events surrounding the transfer of Netherlands New Guinea to Indonesia. Vlasblom was present during the Second Congress and began to speak with a great number of sources and set himself the task of writing a history of Papua that would answer to Papuan concerns, or at least help them to consider and reconsider certain events in their past. While Vlasblom's study attempts to probe under the skin of Papuans, Drooglever's has limited consideration about what it means to be a Papuan. The study by Drooglever is a factual representation of the past; it is 'intentionally researched and composed according to rational principles' (Hirsch and Stewart 2005: 263).

In contrast, the Papuan quest for history invocates different kind of histories with a past that is seen from a local perspective of Christianisation and familiarity with the idea of nation. These histories typically begin before contact with the European world but the pre-European past is condensed into a kind of limbo between Genesis and the arrival of the missionaries, as if Papuans have since God's creation been waiting for God's Word to reach them. Papuans, have, as Epeli Hau' ofa notes for the Pacific in general, 'no history before imperialism' (2000: 456). They live, in terms of the Dutch journalist Anthony van Kampen, in a land that God forgot (Het Land dat God Vergat, 1967). Locally this perception is reflected in histories that suggest a strong attachment to an ancestral homeland that is often, in Christian terms, conceived as a blessed, holy land. Or, as Benny Giay writes in his study of Zakheus Pakage, the religious leader of the Wege communities among the Me in the Wissel Lakes region of the Western Central Highlands of West Papua:

Religion is ... part of the collective memory of the society's past which shapes its view of itself and its identity and the aspirations of the society to preserve such an aspiration ... The rise of Zakheus's communities and indigenous theological awareness can be seen as a new consciousness to preserve the history of their communities and identity in the midst of change and opposition (1995: 10).

In all three narratives discussed in this paper land features as ancestral homeland. Clearly, the quest for authenticity brings along an attachment to an ancestral homeland that is different from the kind of attachment to the land described by Melanesian anthropologists in terms of identity-through-place. Chris Ballard points out that for the Huli of the Southern Highlands of Papua New Guinea, this sense of connection to the land

finds expression in the common statement that water from the streams of one's own land is the sweetest - all other streams taste different and 
this taste is one of the markers of difference that establishes identity. If you were to take the Huli out of [the] Haeapuga [Basin], as one group, they would no doubt thrive - as Huli do in all the metropolitan centres of Papua New Guinea. But without access and reference to their land, they would cease to be Huli. Urban Huli remain Huli largely through reference to other Huli, and particularly through those who remain 'in place'. Conceptions of what it is to be a social being are grounded in a specific territory (Ballard 1997: 50).

In his study of Reite at the Rai Coast of Papua New Guinea, James Leach similarly shows that 'the incorporation of land and place into a history of social relations is where life exists' (2003: 29).

The three historical narratives do appeal to the idea of descent from an ancestral population that has been living on this land for ages, but they follow a genealogical model that is not traditional Melanesian but that belongs to the discourse of the state.

The genealogical model is deeply implicated in the discourse of the state: indeed it is the principal source of legitimation for the state's sovereign entitlement to defend and administer its territory in the name of the nation. For the state, the land belongs to the national heritage, and is held in trust by each generation of citizens on behalf of their descendants (Ingold 2000: 151).

The Indonesian state suggests that the current generation of Indonesians can trace their ancestry to ancient kingdoms whose mandalas stretched territorially all the way to Papua (and Sabang at the western end). Moreover, these kingdoms embody the virtues of the Indonesian nation. According to nation-builders like President Sukarno and President Suharto, the land of Papua is an integral part of this heritage. The inclusion of the land of Papua in their nation-building narratives not only meant the completion of the (post-colonial) nation; it was also an act that is legitimised on the basis of the state descending from kingdoms that are said to have territorially included Papua. But the limit of this nationalist model is illustrated by the three cases here. What they show is a tendency that James Scott, in the Art of Not Being Governed (2009: 307), describes as the mobilisation of people against the state around the idiom of state formation, with appeal to the same kind of genealogy, either with roots in Papua and its near or distant foreign lands or with roots in Indonesia's mythological past. Radical opposition then 'is a question of redistributing the cards in an existing card game, not a question of whether to sit at a table at all or, for that matter, to throw the table over' (Scott 2009: 303). 


\section{The cycle of man's civilisation}

During the first few months of my first fieldwork in the south-western Bird's Head of what back then, in the early 1990s, was still called Irian Jaya, I was often accompanied by Albert. ${ }^{3}$ Albert had just returned home from Jayapura where he had obtained a LL.M (Sarjana Hukum) from Universitas Cenderawasih, and while busy trying to secure a job in the district or regional government, he was interested to learn about what I was doing. Although my fluency in Indonesian was still limited, our conversations often revolved around challenging existential questions such as the identity, status, and future of Papua and the Europeans. Albert's thoughts on these matters showed signs of his exposure to a university environment. He described to me an atmosphere of confusion. Most students often voiced anti-Indonesian sentiments and employed texts and theories to underpin a sense of being different as Papuans, often accompanied by reflection on histories of ancient migration to New Guinea, trade connections with Moluccan sultans, Christianisation, Dutch colonisation and Indonesian annexation. At the same time, he noticed that people's noses were oriented towards Indonesia and its government structure that offered tenured jobs and prospects of promotion to head of district or even governor.

'Why is no one looking at Melanesia if that is the region where we tend to affiliate ourselves with when it comes to roots, race and culture?' Albert asked me once. Just a few weeks earlier I was in Jakarta arranging my research permit and affiliation with the Indonesian Institute of Sciences (LIPI). Reflecting on Jakarta's modernity, I told Albert that I could understand why such urban environments as well as the grandness and power of the Indonesian state and nation arouse the interest of Papuans living in the margins. Albert agreed and continued by telling me about the experiences of his brother Yopi, who was doing his studies in medicine at a prominent university on Java. ${ }^{4}$ Every time Yopi came home to Teminabuan he brought a lot of electronic gadgets for all his siblings and friends and last year he even brought a stereo set and VCD player and a wide screen TV for his parents. Besides gadgets Yopi also brought home experiences of being discriminated against on Java. People had been calling him a filthy black (hitam kotor), a Papuan pig (babi Papua) and an ape (monyet). These are among the more common kind of verbal harassments that many Papuan students in urban environments throughout Indonesia have to endure (see Munro in this volume). 'You know, this is just one element of all the things that "Indonesia" does to stop us Papuans from reconnecting with the Netherlands.' I was intrigued by this observation and asked Albert to elaborate, which he did by drawing the following figure.

3 Albert is a pseudonym.

4 Yopi is a pseudonym. 


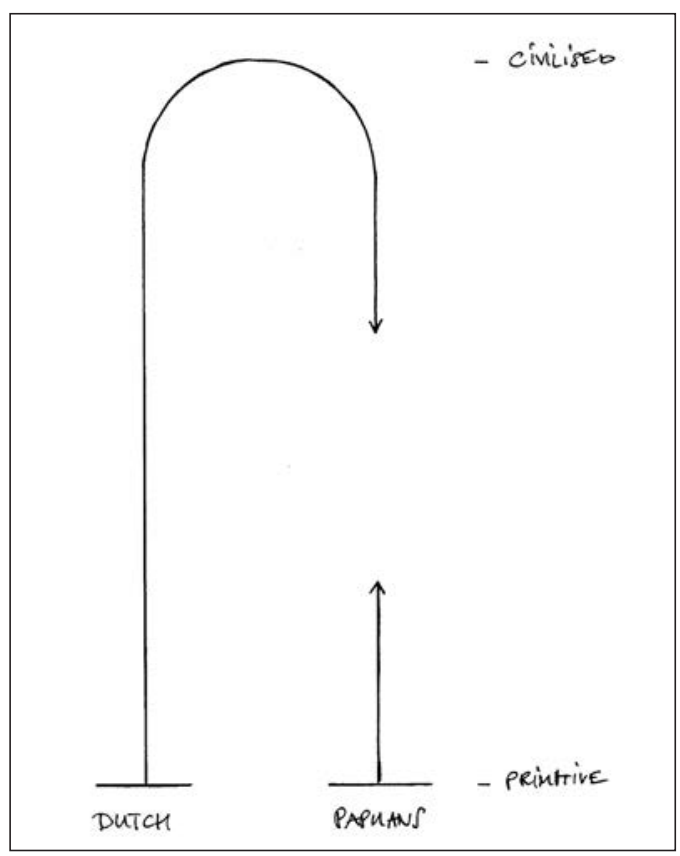

Figure 4.1. Albert's 'Cycle of Man's Civilisation', drawn on the basis of the original rough sketch.

Source: J Timmer.

\section{Albert explains:}

This curve is the cycle of man's civilisation. Man is complex. He has thoughts, concerns, wishes, feelings and so on. And man has a life trajectory, a path, of his own. At whatever stage he is at along this path, he needs a lot of other people to survive while at the same time he feels that he can handle everything by himself. When man is young he needs others to feed him and assist him in learning things, but once he is grown-up he feels that he can do everything by himself. Then, when he has grown old, he will realize that he needs others to help him. He will need help to cut a walking stick, he needs glasses made by someone, and so on. This is the journey or path of life. This path affects his thoughts, his wishes, his concerns, his feelings. There will be moments during which he thinks he is still strong and fit while in fact he already needs a stick for walking. He must return!

The small child who needs supervision is like peradaban primitip ('primitive civilisation'). Because he is still primitive, he will highly value the person who comes and helps him. He will think that the other has better thoughts than him and he will begin to consider himself to 
be bodoh ('stupid'). An example: Orang Irian ('the Irianese') were still primitive according to the Dutch when they first arrived here. They brought him Christianity, education, clothes, and so on. The people here thought 'yes, that is all good' and they began to follow the ways of the white man. In those days the people of Irian knew all kinds of things including secret knowledge like the tradition of wuon. ${ }^{5}$ But when the Dutch said, 'do A', they did A, and when they said, 'do B', they did B. But after the Dutch left and went back, the Irianese menjadi dewasa ('came of age'). 'Coming of age' (menjadi dewasa) he developed many different thoughts and began to want a lot of things, and his feelings began to evolve and he started to think that he does not have everything. He became individualistic and forgot about the community. In abstract terms, he has come of age only halfway primitive and moderen ('modern') [see the diagram]. His identity shattered.

Grown-ups and their ideas about what is modern affect the Irianese, but to get to the modern stage he needs those grown-ups. This is where we are at. While the Dutch in the past said that our culture is primitive the Indonesians who arrived in Irian Jaya later on say that it is kuno ('obsolete', 'bygone') while suggesting that the latest, the modern is to be found in Jakarta. The Dutch said that they would help us to get there and did put effort into that. The Indonesians simply say that they have it and that our ways are hopelessly out-dated. The Indonesians have already reached the modern and when they took over Irian Jaya they realised that some are not yet modern. This is a lingkaran setan ('vicious cycle') in which the difference in development between Papua and Indonesia aggravate each other, unstoppable. You see, it will worsen the situation.

At present all the policies of the Government of Indonesia are pusing ('confused'). Indonesia wants to become modern without recognising the value of the original. Indonesia is a strange state. Other countries like the Netherlands want to return to yang sempurna ('the perfect') because they like that. At the same time, here in Irian no one wants to return to the adat ('customs') of the past. Who wants to learn those things that belong to the past? The Dutch and the Indonesian government have forbidden them. They now suggest that tourists may be interested and they may bring a lot of money. Kacau! ('Chaos!') According to me this is not good. It is nonsense.

5 Wuon is the shorthand way of referring to a complex of rituals focused around male initiation. The wuon cult was active throughout the region until the Dutch missionaries forbade it in the 1950s. The rituals were lead by na wuon, ritual leaders who would conduct the initiation and also use their powers to ensure fertility of gardens, guarantee successful hunting and fishing, heal the ills and battle evil powers such as witchcraft (lait). 
Albert adopts an evolutionist model to establish a paradigmatic truth about Papua. For Europe, James Ferguson points out that the effect of evolutionist models of history 'was to transform a spatialized global hierarchy into a temporalized (putative) historical sequence' (2006: 178). This evolutionary scheme was applied to the newly emerging nations in the regions that were decolonised following the Second World War and became the way in which development and state-building in the post-colonies is understood. Like the West used to map history against hierarchy and development time against political status (Ferguson 2006: 177), Albert, among many others in West Papua, map the backwardness of Papuans against an evolutionary hierarchy with Western countries and Indonesia at the top, and Papua at the bottom.

Albert mythologises this bottom to 'the perfect' (yang sempurna) in terms of universal and inescapable evolution from being to becoming, from the temporal to the primordial, relating to an original, authentic and timeless truth about Papua. The main issues around inauthenticity or departure from the perfect is, according to Albert, that people in the West are individualistic, that they do not appreciate the importance of relationships and they have lost their connections with the land. He sees that 'Indonesia' is bringing a similar kind of development to Papua and this conflicts with being Papuan.

\section{Genesis and time}

Albert's narrative illustrates how many in the Teminabuan region of the Bird's Head understand Genesis in terms of their own past. The primordial perfect state of being called Toror in the Teminabuan region features as the biblical Garden of Eden in most contemporary accounts of local stories surrounding the alleged parallels between the wuon initiation cult and Christianity (see Flassy 1985 and 2002). During my research in the early 1990s the few still living na wuon (ritual leaders) suggested that they knew the details about Toror but shrouded them in mystery. This mystery, in particular in the present situation in which living na wuon are exceptional individuals who retain the meaningful tradition of a oncedominant elite, leads to a multitude of conclusions about Toror.

Toror pictures completeness and unity before the present world came into being. According to Flassy (1985: xii-xiv), this period is called qolm mqsya in Tehit, meaning 'the carrying spirit or the guardian spirit'. What Flassy means to say is that people believe that in Toror there was only one spirit. Some informants explained to me that I should understand this ni mres ('one spirit') as kahan ('the truth, the core secret, the first and most powerful'). This primary state of being is seen as a world where one can get to only when all power and lost knowledge is returned to Imyan. 
As said, many compare Toror with the Garden of Eden, but it is not just that Genesis provides an account of the origins of reality - which it does - but that the kinds of meaning that people give to Genesis is related to their ideas about Toror and that ideas about Toror influence the way they read Genesis. The prevailing interpretation of Genesis has a particular temporal dimension not unfamiliar to Western Christians: it is typical of an apocalyptical interpretation that suggests a return of man as mortal creatures to the Garden of Eden at the End of Days (Hendel 2013: 9). This is reflected in Albert's narrative above, in which the suggestion is made that the present imperfect state will come to an end with the return to the perfect era (yang sempurna), a paradise.

The other stream in Albert's 'Cycle of Man's Civilisation' revolves around the idea of knowledge in the way it envisions a world that has superior knowledge and is already developed. This is also a dominant concept in Jewish and Christian religious thought (Hendel 2013: 9) that has been brought to Papua through missionisation and colonisation. A story that Seppy Kemesrar (37, Haha village, Teminabuan district) told me further illustrates this and highlights some of the variety of ideas held about Toror:

The old na wuon suggest that at first there was Toror. We do not know about Toror because it is their secret. But from the Bible we know that God created man. Maybe he did create man but not all human beings. From there, the soul [thalye] went to other people. Adam was created directly by God. I indeed believe that Allah did this. He created Adam in His own image. Adam was similar to God. But I don't believe that after that, God created all other human beings. He did not give thalye to every single person.

What we see in the world today or what we hear from the many stories that are doing the rounds here, is that there are people who originate from a certain place and others from another place. This means that God created humans as animals, some appear here, and others appear there. Maybe God gave the breath, but where humans would appear was not restricted to the Garden of Eden. For example, the Kefi people [a clan living north of Haha] came out of a hole in a tree. There are also people who came out of the ground, like the Mejefat Lumna [Kemesrar's main ancestor]. How can this be?

These people may not be children of God. They are animals who might have got their thalye by God but they were not created in His image. He brought these beings into being but he did not create them. There is difference between bringing into being and creating. God created Adam but he brought humankind into being. All our genealogies go back to Adam. I therefore question the story that people here tell about their 
ancestors coming from a hole in the earth. Like Sagisolo, what is the truth about their origin story? The Sagisolo people come from the Kefi tree. Flassy people came out of the ground. There also the Saflembolo people who came out of the ground at an anthill.

Perhaps the reason behind this is that there were not enough people to inhabit the earth. When God realised this he found other ways to bring people into being. He did that to fill this earth with human beings. God has already promised to the people of Israel in the Old Testament that there should be many people. As many people on earth as there are stars in the sky.

Seppy Kemesrar, Haha village, May 1995.

Kemesrar's discussion should be viewed from the fact that, as I explain in detail in Timmer (2000), among the four groups in the village of Haha, the Kemesrar people most closely relate to Toror and that by extension, others are perhaps animals and may not be God's children. This Christian twist to origin stories marks the importance attached to closeness to God and Toror and the general concern with the cosmic unity in the world. The Toror that Kemesrar describes is the state of being of his Kemesrar ancestors when they still resided at Baimla. Baimla was an 'entrenchment' (mla) situated on an island in the estuary of the Segun River, some 40 kilometres east of Cape Sele on the westernmost point of the Kepala Burung Peninsula.

Baimla was important to the rajas associated with the Sultanate of Tidore as a place where forest products and manpower could be gained. Baimla might have been one of the nine negorijen or native villages mentioned by De Clerq in 1858 (in Kamma 1947/48: 540). ${ }^{6}$ Although the inhabitants of Baimla enjoyed a good life, one major problem concerned them. The story that recounts the migration of the Kemesrar people tells how the inhabitants of Baimla feared the death of newborns because of the suffering endured by expectant mothers. As prevention, they had to cut open her belly to save the child at the expense of its mother's life. ${ }^{7}$ All children in Baimla were thus raised as motherless children and fed with water instead of breast milk. The people of Baimla cut children from their mother's womb until there came a woman from the Krimadi people who was exchanged for cloths by the Kondjol people at the Kaibus River.

\footnotetext{
6 People from Biak founded these villages as colonies or trading posts on the mainland of the Bird's Head Peninsula. In this part of West New Guinea, it was mostly Biak people who had long distance trade relations and spread the Biak language as a trade language throughout the western and northern coast of the Bird's Head, the Raja Ampat Islands and Eastern Maluku. The origin story of wuon in which Bauk brings a metal axe into the interior of the Teminabuan area relates to this trade history (see Kamma and Kooijman 1973: 25-26). 7 The idea that formerly birth could be given to a child by means of a 'Caesarean' only is also reported to exist among Inanwatan people (Lotgering 1940: 19). After having seen a dog bearing puppies, the women realised that they should do it in a similar way.
} 
After living with the people at Baimla for some time, the Krimadi visitor taught her hosts the proper way to give birth to a child. When the people saw that the new techniques worked, they began to admire their guest for her knowledge. For that reason, the people of Baimla moved to the birthplace of the Krimadi woman, in the direction of where the sun rises. They readied their canoes, sewed sails and prepared provisions for the long journey. In another version of this story, the people of Baimla left unprepared. Because of a conflict surrounding the adulterous act of a Kondororit person, the Kemesrar people had to flee. Others stressed that the story is a Christian story that tells that people had to move away from Baimla because water was overflowing the island. It suggests that Baimla is in fact the biblical Babel and that Noah saved all living creatures from Baimla, the actual origin place of all people.

These stories reveal that people do not read the Bible as a disparate set of texts but instead as a cohesive whole that reveals the nature of local history, the unfolding of time and the purpose of history. The moment Papua's past becomes part of Christianity's eternal truths they become remote in relation to other histories such as migrations, wars, the advent of missionaries, the establishment of the government and so on. Becoming part of religious representation that gives privileged status to Genesis the collective memory about this period, in terms of Halbwachs,

subsists in a state of isolation and is all the more separated from other social remembrances to the degree that the epoch in which they were formed is more remote, so that there is a more marked contrast between the type of life and social thought that they reproduce and the ideas and modes of human action of today (1992: 91).

Both Toror and the ancient Papua sempurna in Albert's cycle are fixed ones and oblige people to mirror their current ways of doing against it. We will keep perception of time in mind until we begin to analyse the Constitution for West Papua which builds on similar ideas and gives an even more compelling sense of how people in this part of Papua bring to light an idealised past and thereby providing biblical underpinning, relationship and dignity to the idea of a Papuan nation.

\section{Journeys between Java and Papua}

Also not agreeing with the Western telos of modernity but showing identification with Indonesia's nation-building mythology, in particular its use of a genealogical model of history, is Reverend Jusuf Onim's (1998) brief history of the village of Wersar (also in the Teminabuan region) that recounts the evolution of Onin culture in relation to regional cultural dynamics and its rootedness in the 
Kingdom of Sriwijaya and the Kingdom of Majapahit. According to Rev. Onim, the people of the Onin Peninsula are mentioned in the Nagarakrtagama, a 14thcentury Javanese eulogy to the monarch of the Majapahit Empire, and their roots can be found there. The Nagarakrtagama contains detailed descriptions of the Majapahit Empire during its greatest extent and indeed includes a reference to Onin in Papua. Indonesian nationalists evoked these two kingdoms as an illustration of precolonial national unity (Reid 1979). Reid points out that in the eventual assessment of a synchronic history and national destiny,

it was seen appropriate to concentrate on the grandeur of these precolonial kingdoms in a one-dimensional fashion, rather than to inquire further into their diverse social structures, belief systems, and economies. The question of national identity had in essence been resolved, as arising from common oppression by the Netherlands (Reid 1979: 290).

In this national history, as President Sukarno would point out later, Indonesia lost its magnificence with the arrival of the Dutch heralding hundreds of years of humiliation. In particular, during the New Order period, policymakers focused much on reviving the glory of the nation through highly centralised nation-building projects that were always metaphorically rooted in the national but largely Javanese past. Students learned virtually nothing of the political life in the archipelago after 1600, let alone the existence of different histories and cultural dynamics in the outer regions. Papua only became firmly embedded in the national narrative during the Trikora struggle against the Dutch, who were still holding on to the territory after Indonesia had proclaimed independence in 1945, and who finally had to accept Indonesian sovereignty in 1949.

In their struggle against Indonesia, people in Papua are similarly concerned with forging national histories to underpin ideas of unity. But in the absence of a past that shows similarities to glamorous old kingdoms, people tend to emphasise the moral greatness of past cultural traits that were destroyed with the advent of Indonesian colonialism but find support in Christianity, another major element in (most) Papuan cultures that sets them apart from Indonesia. It is therefore quite surprising to find a local historiography that includes references to the Nagarakrtagama and the two kingdoms central to Indonesian nationalism.

According to Rev. Onim, the Onin people and people in Papua as a whole enjoyed a special and respectful relationship with the Kingdom of Sriwijaya and the Kingdom of Majapahit, and they provided Papua with an authentic name and identity.

The book Negara Kertagama, was written by the Mpu Prapanca in 1364/65. The verses 13, 14 and 15 contains place names from Irian. Mohammad Yamin [1903-1962, a well-known nationalist, historian, 
poet, playwright, and politician who has written about Indonesia's struggle for independence, the history of Majapahit and who is believed to be the author of the Pancasila, the five pillars of the Indonesian nation], on the basis of a study of verse 14, is of the opinion that the term Wwanin or Onim is identical with region VIII of the area controlled by Majapahit. The verse is as follows:

Butun baggawai kuni ggaliyao mwang I(ng) salaya sumba solot muar muwah tigang $i$ wandan ambwan athawa maloko in timur ewanin ri sran ning angeka nusatutur (Koentjaraningrat [and Bachtiar], 1953 [sic. 1963]: 47-56)

Apparently, these places, mentioned in verses 13, 14 and 15 were within the sphere of influence of Majapahit which at that time had its capital at Triloyo, Mojokerto, East Java. The term Wwanin (Onin) is still used in the village of Wersar in poems (songs). One such local song is as follows:

Wndindi wdo wska wana Wanin woro are wdo whriak nai ma afaaf vein eeehhh (An Onim Song).

This expression translates as: 'May the thunder bring changes, so that the weather of Wanin (Onin) will be fine, so that we can sail across to Wanin (Onin)'. The term Wanin (Onin) is only used in the communal poems and songs of the village of Wersar, Teminabuan. The poem (song) describes life on the sea along the entire coast of the Onin Peninsula and the Bird's Head. The term Wanin is the oldest name to identify the island of Irian. Other names such as Nieuw Guinea, Papua Barat, Irian Barat and Irian Jaya, are names that have been given by foreigners. Only the name Wanin (Onin) and the name Janggi or Tungki, as used by the Chinese sailor Chau $\mathrm{Ju}$ Kua in the 13th century (8th century) after the Kingdom of Sriwijaya, and during the Kingdom of Majapahit are original (1998: 1-2).

In the conclusion of the paper, Rev. Onim states that

the name Wanin ... [does] not have a political or racially pejorative connotations as is the case with the name Papua. The connection with Sriwijaya and Majapahit may not have been permanent. Irian was not an area governed by either, but trade relations existed between the two areas (1998: 10).

In his history of Papua, Rev. Onim simulates the idea of sovereignty as enjoyed by ancient Javanese Kingdoms that featured as a motivating rhetoric during the Indonesian independence struggle and still underpins the nationalistic sovereignty of the current nation-state of Indonesia. If Indonesian state sovereignty can be founded on the basis of the history of ancient kingdoms 
then, in Rev. Onim's view, the current government should logically recognise Papua as sovereign because it featured as an acknowledged sovereign region in the past.

Rev. Onim's claims about the connections between Onim and Indonesian state mythology as underpinning the sovereignty of Papua and the hegemonic character of Onin culture in the South-western Bird's Head region has made him appear to many in the Teminabuan region as a hero. Not only is he the first from the village Wersar to become a reverend and teacher in the Theological College of the Evangelical Christian Church 'I.S. Kijne' (Sekolah Tinggi Theologia Gereja Kristen Injili 'I.S. Kijne'), he has also established himself as a historian who not only knows local legends but can meaningfully connect them to the world of myths underpinning the Indonesian nation. It is therefore no surprise that I came across many of his followers, one of them whose narrative I recount here. This narrative is inspired by Rev. Onim's history of the region and was prepared for a large meeting (sidang akbar) scheduled to be held in 1996. The purpose of the sidang was to resolve, 'once and for all', the ownership of lands in and around the town of Teminabuan: the villages of Kohoin, Wermit, Wersar, Aibobor, Seribau and Kohoin; and among the following descent groups: Thesya, Salambauw, Momot, Wamblesa, Kamesok, Safledrar, Kondororit, Flassy and Kondjol.

While the most important detail in other Tehit groups' histories is their claim of precedence, which is backed up by early contacts with the Wamblesa people, the Kondjol people of the village of Wersar suggest that they arrived even earlier. Many Kondjol people are changing their surnames to Onim or Onin to stress their origins and ethnic identity as their migration histories relate to the Onin Peninsula, where they lived together with the Anggiluly people. Among the Onim or Kondjol people, many claim that almost every important and heroic historical event in the Teminabuan area was due to the powers and influence of their ancestors. Rev. Onim (1988: 26) claims that it was due to the efforts of the Onim ancestor, 'Raja Angguok', that missionisation in Teminabuan, Ayamaru, Aitinyo and Ayfat got off the ground smoothly. ${ }^{8}$ Presently, there is a strong Onim/Kondjol political lobby to claim the status of first comers and thus ownership of Teminabuan town and the Kaibus River. Their heroic history also

\footnotetext{
8 See Kondjol (1996: 4). Spelled as Anggok, this raja is mentioned by the government official Dumas in his 1911 Memorandum for the Afdeeling West Nieuw-Guinea (1992[1911]: 12) as the only person among the people living in the Kaibus River area on whom the Dutch traders and government officials could count. In current local histories of Kondjol people, Angg(u)ok plays a heroic role. Part of these histories is a song about his courageous travels in the area between the Kaibus River and the Seremuk River. Apparently, he was very successful in capturing people whom he sold to rajas at Onin and occasionally to rajas at Salawati (see Wanane 1991: 55). He is often portrayed as a mighty man who ruled over the coastal area stretching from Inanwatan all the way to Cape Sele.
} 
wants recognition that the Onim/Kondjol people have contributed to the advent of Christianity. As evidence, they often refer to the important relations that the Onim/Kondjol people had with rajas and the sultan of Tidore.

Some go even further to suggest that the Onim/Kondjol history is still more authentic and more deeply grounded in larger spheres of power. Mince Kondjol ${ }^{9}$ recounted in detail a history claiming that they descend from the Javanese. Their having possession of a Javanese wavy double-bladed dagger (keris) and a small Buddha statue afford further proof of this. The story told to me by Kondjol goes as follows:

We originate from the island of Java, at Tanjung Priok, the presentday port of Jakarta. In the tenth century, there was a war between Islam and Buddhism. This was a religious war. Buddhism lost and was dispelled to Bali. Our ancestors kept a kris and the [Buddha] statue of a sitting woman. Because of this war, our ancestors, named Onain, fled to the island of Ternate. They sailed to Ternate with a sailboat [perahu layar]. They arrived at Ternate in the afternoon at around 4 p.m. and encountered the Anggiluly people.

During the first night, the Anggiluly people accommodated the Onain people and the next day our ancestors built a house for themselves. In the early nineteenth, a religious war broke out. The Onain and Anggiluly people wanted to leave the island because they were afraid of Islam that was laying siege over the whole of Eastern Indonesia. Where could they take refuge? Each group loaded its possessions on a sailboat and headed to Irian. They already knew where Irian was because they had been there to get birds of paradise.

At 8 a.m., they left from the beach of the island of Ternate, met the sultan, and steered towards Irian. In the middle of the night, it was so dark that they lost track of each other. The Anggiluly people went to the island of Ega. In the morning they saw an island shaped in the form of the letter O. They called it Onin. The Onain people travelled to Kowiai and saw that its shape was similar to a songkok (a fez-like cap). They named the island after the Ternate word for this cap: Kowiai.

Mince Kondjol, Wersar village, November 1995.

The story continues to describe how the Onim people settled in the Teminabuan region and how later arrivals established relationships with these first comers. This historical narrative illustrates that in situations of conflict, in this case over land, groups may opt to enlarge their genealogy to include connections

9 Mince is a pseudonym. 
with Java. Such historiography follows a framing that is heavily influenced by the structure of the scripture reminiscent of the ancient-world formations that Benedict Anderson in his Imagined Communities calls 'the sacral cultures' (1983: 20). In Anderson's account, sacral cultures such as the Ummah Islam, Christendom and the Buddhist world imagined themselves through the medium of a sacred language and written script.

This is what makes the stories about Onim so fascinating: they can be read as a story about Onim people's registering their relationship with ancient Javanese kingdoms and including Papua firmly in the phenomenon of Indonesian nationalism, of which only phantoms feature in Papuan minds. In recognition of the power of the Indonesian national narrative, they produce a story about Onim culture imbued with a quality of being everywhere but nowhere in particular. It is historiography that accounts for timeless and non-generational connection that instead builds on the idea of paths and journeys between Java and Papua. Another strategy for establishing a paradigmatic truth for underpinning a Papuan identity and a Papuan nation would be to invoke a shared genealogy to a common past and/or common culture, as the following case will illustrate. In both processes, the past is invoked based on present circumstances as a way for previously distinct social groups to redefine themselves and their relationship to one another. Applying the genealogical framework that is central to the authenticating myth of the Indonesian nation does this.

\section{Papua's Constitution}

The previous narratives date back to the last decade of the New Order regime. Following the regime's demise with the fall of President Suharto in 1998, Papuans became more outspoken about the status of their land and their interpretations of national history. The period immediately following the resignation of Suharto has been described as the Papuan Spring and in the more socio-political accounts it is seen as marked by demonstrations, flag raisings and heightened expectations about radical changes in inequality and marginalisation amid a flurry of messianic dreams (Van den Broek and Szalay 2001; Chauvel 2005; Kirksey 2012).

During this period Papuans became increasingly vocal towards local and distant audiences communicating historical, racial and national arguments as part of their pursuit of freedom. Most publications so far produced tend to discuss human rights violations and the injustices surrounding the transfer of Papua to Indonesia (for example: Alua 2002; Giay 2000; Karoba et al. 2002; Maniagasi 2001; Pigay 2000; and Raweyai 2002). Only a few, pace Giay (2000), imagine how a new state or nation might be constituted. Standing out is Basic Guidelines, 
State of West Papua: Papua-Melanesia Threefold Logic, Basic Ideology, General Governance, Constitution of West Papua (Flassy 1999), the founding document for an awaited sovereign state of West Papua. The document was edited by Don A.L. Flassy, one of the most prolific Papuan writers, whose work reflects broad interests, ranging from linguistics and anthropology to natural science and governance. ${ }^{10}$ Basic Guidelines demonstrates Flassy's erudition and creativity, and, like the two previous narratives, it is a potent blend of biblical, customary and modern discourses. Being a constitution and not an outline of the evolution of mankind or a local historical narrative, the text revolves even more intensely around the ideas of sovereignty and morality.

According to Basic Guidelines, the principles behind the constitution are that Papuans are: 'by full glory and warship [sic.], admitting that, The Nation and Country of Papua, is under the authority and truth magnificence of God The Lord - Yahweh, Jesus Christ ...' Next, in capitals, the text continues:

\section{AS COSMOPOLITANS}

WE, THE PEOPLE OF THE PAPUAN NATION

\section{DECLARE}

Based on the experience we have been undergoing, that colonialism of any kind and name being exercised by any nation is not suitable at all with humanity and justice, and contradict with principles of freedom and human rights. Therefore colonialism must be continuously combated and disappear from the world's surface. For this reason one must be involved in bearing real responsibility for the sake of freedom and human rights....

\section{AND FOR IT'S REALIZATION}

Endeavors are required in full responsibility to The Papua-Melanesian Triplefold Logic, that is The Papuan Principle of Triple Luster of mercy, allegiance and honesty with full respect to The Triple Spirit of Melanesian Brotherhood principles of one nation, one soul and one solidarity (Flassy 1999: 21-22).

We see here a creative combination of Christian principles, the popular OPM or 'Free Papua Movement' slogan 'one people, one soul' (see Ondawame 2009), international human rights principles, anti-colonial discourse and a fascination with numerical correspondence. Remarkably, 'one nation, one soul and one

10 Basic Guidelines is so far the most developed constitution for Papua amid a wide variety of tribal constitutions that are written mostly in response to (threats of) marginalisation, resource exploitation, deterioration of morals and questions of leadership. 
solidarity' resonates with catchphrases in the five Irian Barat (the then name for the territory) speeches by President Sukarno. Sukarno's speeches regarding Irian Barat are mainly anti-colonial and speak of Indonesia's right to re-establish the unity of the nation, as it allegedly existed during the struggle against the colonial powers. ${ }^{11}$ This unity includes Irian Barat and therefore the Dutch had to leave West New Guinea. Indonesian National Party (PNI) ideologue and then Minister of Information, Roeslan Abdulgani further developed this premise in Dari Sabang Sampai Merauke: Satu Nusa, Satu Bangsa! ('From Sabang to Merauke: One Country, One People!') (1964), a guideline for the Indonesian nation (now including Irian Barat). Around the same time in the Bird's Head region, the OPM was shaped in terms of a struggle for a separate nation. Indonesian propaganda inspired their attempt at nation building: Satu Bangsa, Satu Djiwa ('One People, One Soul'). ${ }^{12}$ Paradoxically, in spite of the antiIndonesian bent of Flassy's initiative, his rhetoric resonates with the rhetoric of Indonesia's liberation of Netherlands New Guinea in the late 1950s and early 1960s. For all the racial and ethnic tension between Indonesians and Papuans, for all of its anti-colonial rhetoric, Basic Guidelines also emulates Indonesian state ideologies from the preceding decades.

By emulating the Indonesian state, Flassy powerfully unmasks the Indonesian state and presents an alternative state, or a state within a state, a sovereignty within a sovereignty, to be built on the remnants of a lost Edenic order in which, as I will illustrate, Christian principles converge with customary rules (adat). Adat and mission Christianity mutually assent to each other, and together they are tantamount to justice, dignity and sovereignty - or 'one people, one soul, one solidarity'. As indicated above, Christianity is a pervasive force in the formation of culture and local, national and transnational identities and its scripture is a likely source of inspiration for constructing a state. Papua is overwhelmingly Christian in the sense that the majority of the population grow up with a basic acquaintance with the Bible, Christian hymns and Christian doctrine. For many Papuans from all walks of life the Bible provides some key discursive and expressive resources. As a result, biblical vocabulary and narratives colour people's life-worlds significantly. 'Chosen people' in relation to Flassy's statebuilding project is prominent and this is illustrated most clearly in the constitution's Welcome Speech (Flassy 1999: ii-iii) that is signed by Theys $\mathrm{H}$. Eluay, the charismatic and colourful leader of the independence movement almost immediately after the fall of Suharto. ${ }^{13}$

\footnotetext{
11 See http://www.papuaweb.org/goi/pidato/index.html for Sukarno's speeches on Irian Barat.

12 The history of the OPM is not documented in any great detail yet (but see Vlasblom 2004: 469, 486636, Ondawame 2009, and Djopari 1993) but the mimicking of Indonesian nationalist slogans as well as its command structure and dress style resembling the Indonesian military, certainly form interesting aspects for explaining its powers and paradoxes.

13 Through his old connections with the Golkar Party and ongoing business friendship with people in the military, Eluay was seen by many as paving the way to independence. He was brutally assassinated by officers in the Special Forces (Kopassus) of the Indonesian military on 10 November 2001 (Giay 2006).
} 
The Welcome Speech includes a long list of key elements that together underpin the idea that the Papuan Nation is unqualified, natural and divine. A closer look at these suggest a precedent for Flassy's constitution. The first two elements are the shared suffering of Papuans under the New Order government and the popular idea that God chose Papua as a holy land with the first arrival of white missionaries in 1855. God's plan for Papua and the arrival of Christianity needed, as Eluay writes, a longer journey in which God 'allowed' the colonisation of West Papua:

[He] allowed the Papuan people to undergo colonization under the nation and government of infidel people, namely Indonesia, for 36 years, starting from 1962. Under these conditions, the Papuan Nation grew and discovered itself as no longer being tribal groups surrounded by darkness, but seeing clearly God's brilliance in blessing our nation and land (Eluay in Flassy 1999: ii).

The Papuan nation is the fruit of God's desire. In his words, it is 'absoluteness desired by the absolute truth, namely God, the Creator of sky and earth'.

The horrifying deeds have been successful in uniting the Papuan people out of their isolation, darkness and hostility. They ware [sic.] earning the Bright of the Gospel of Christ which had formed these huge of tribe to be a Nation on a by God Lottery [sic., Eluay means the lot of land as allocated by God to the tribes of Israel] Land since 5th December 1855. Which His Wisdom and Mercy being then on The 1st December 1961 as bestowed declared its own as a Nation and State of West Papua (Eluay in Flassy 1999: ii).

Inverting as it were the familiar modern European history production which suggests that development moves from barbarism to civilisation through secularisation (see Ferguson 2006: 177-182), Papua's coming of age is in God's hands, and the constitution, Eluay hopes, 'will fulfill our common desire and God's mission for this land Papua' (Flassy 1999: iii). Law here is the culmination of God's mission to Papua and it has a sacred origin.

Throughout Melanesia, the domains of the state and religion, as well as custom, are in most contexts hard to conceptually separate (Timmer 2000). Also, the kind of statebuilding that Flassy is engaged in shows that there are no complex or problematic relations between state and religion. On the contrary, the Papuan nation is seen as part of God's plan for humankind and its people a chosen people destined to play a role in the fulfilment of the book. Through reading the scripture, many in Papua develop a particular notion of nation that is not in anyway antagonistic to a secular variety. Such a secular variety is not part of the equation, if ever pondered. The Papuan notion of nation thus also differs 
from that documented for nation building in Europe by Benedict Anderson in Imagined Communities (1983) which, as noted by Smith 'turn[s] its back on religion and the sacred, in favour of print and vernacular language' (2003: 20). Basic Guidelines shows that people believe that they are not moving from a religious world to a secular world, nor do they think that they replace Christian notions of the origin of the community, morality and membership with those of the nation.

As mentioned above, the Bird's Head features in collective memory as the region that God chose for the dissemination of His word to the inhabitants of Papua. This particular nationalist narrative recounts the arrival of the German missionaries of Lutheran conviction Carl W. Ottow and Johann G. Geissler on the island of Mansinam off the coast of Manokwari in Cenderawasih Bay (Kamma 1976: 73). For Papuans, the arrival of the Gospel stands out when narrating the history of their nation (see Young 1997). Throughout Papua but in particular in Protestant and Evangelical circles, the arrival of Ottow and Geissler is exceedingly celebrated with overtones of Papuan nationalism in the shape of flag raising, hymns such as 'Onward Christian Soldiers', and prayers for independence. At a regional level, Manokwari is now known as the Gospel City (Kota Injil) and has seen a proposal for government regulations based on the Old Testament. For now it is important to note that in the constitution the sacred character of Mansinam and Manokwari buttresses the first principle of the Triple Principle of Papua Luster: Mercy:

The emergence of the West Papua Nation had only come true by the willingness of The Mercy or Love of Jesus Christ. In the name of The Lord, Ottow and Geissler, two disciples from Germany had crossed the sea and stepped feet on the island of Mansinam at Dorei Bay, Manokwari. This is The Lottery Land of God (Psalm 125: 3), as stated for its baptism. (1999: 6-7)

Im Namen Gottes betreten wir dieses Land ('In the Name of God we enter this Country') is the alleged first phrase uttered by the missionaries upon arrival at Mansinam. It is often reiterated, in particular by people in the Bird's Head and along the north shores of the territory. This is the region that is most significantly influenced by Protestant and Evangelical missions and movements. Flassy relates it to the meaning of Psalm 125 (1999: 7) which says that As the mountains are round about Jerusalem, so the Lord is round about his people from henceforth even for ever', relating to the common understanding of Papua coming of age as a Holy Land with the arrival of God's Word.

Such statements are not rhetorical ploys to persuade those who would otherwise not be convinced of the foundational value of this attempt at West Papuan state building. Instead they show that the scripture plays an integral part in the 
emergence of concepts of state and nation in West Papua. In significant ways, the constitution for West Papua is part of the fulfilment of the book by Papuans as a covenanted people and thus illustrates the momentum gained by cultural experimentation with the scripture for political invention and state-building.

\section{Conclusion}

To the extent that the three narratives discussed in this paper can be generalised, they highlight a tendency in Papua to borrow historical form from the modernist and Christian conceptions of history, generating ideas about paradigmatic truths found in definite beginnings, in Genesis and in primitiveness. The evolving collective memories portray these paradigmatic truths in relation to widespread nationalist narratives about the arrival of the Gospel, the advent of Dutch colonialism and the transfer of the territory to Indonesia. Many in the region are fascinated by these events and their personal recollections of them enter into intersubjectivity, the collective memory that in turn becomes a fertile ground for the kind of historiographies that I discussed above. By including components of metaphysical principle and paradigmatic truth that are related to Christianity and myths of states and nation, the narratives no longer focus on individual or group histories but on larger regional history and even world history.

It was also necessary to analyse the intellectual effort and creativity involved in these undertakings (see Fisher and Timmer 2013, and Timmer 2013). This not only illuminates the different streams of knowledge that influenced the thinking behind these dissecting and overlapping histories, it also acknowledges the extent to which such histories are the product of competing segments of society that each tries to appropriate them and turn them to their own interests (Lincoln 1989: 38-50). What Lincoln (1989: 38) calls the socio-political instrumentality of mythic discourse is most apparent in the narrative about the Onim people as the historical heroes of the region. This narrative builds on the Javanese cultural heritage that has underpinned Indonesia's nation-building project and attempts to associate the Onim people with Java. This association has significance in local land struggles, and also undermines Indonesia's claim to a nationhood that includes Papua on the basis of memories about ancient Javanese kingdoms.

The Cycle of Man's Civilisation broadens this perspective with a temporal perspective that both encompasses Western development terms and the Christian scripture. In terms of Genesis it suggests that Papua, as the Garden of Eden, lies at the origin of humankind and the history of civilisation. In the course of time, the Dutch climbed up the ladder of civilisation while Papua remained at the perfect paradisiacal stage. Then the Dutch came to Papua and brought God's Word, followed by the Indonesians who made the Papuans lose social 
connections and made them individualistic. Nevertheless, Papua's character as the root of everything, the perfect, survived the tooth of time through the idiom of descent (see Ingold 2000: 135). The Cycle of Man's Civilisation portrays a sense of Papuans being the original inhabitants, being both indigenous and aboriginal, reproducing as it were a thoroughly Eurocentric image of the precolonial world as a mosaic of cultures and territories that was already in perpetuity before history began' (Ingold 2000: 132). Ingold argues that this kind of thinking about indigeneity and originality stimulates awareness of historical continuity in terms of descent. Genealogical connection limited to one specific region then suggests that original cultural traits can be transmitted across generations, along chains of ancestors all the way down to the present generation. The Cycle of Man's Culture does not seek to redefine all distinct Papuan groups under one umbrella-notion of cultural and developmental similarity, yet it evokes the idea that all Papuans share a wonderful past that is meaningful and may awaken and produce feelings of affinity for one another.

The Constitution for Papua is an attempt to unite Papuans through the evocation of 'one soul, one people' for the purpose of state-building. It redefines Papua and its history through the invocation of shared unified Melanesian cultural principles that were still uncontaminated before Europeans and Indonesians arrived on the scene. Yet at the same time, the present conflict with Indonesia stimulates the collective memory that evokes newfound affinities. The Constitution explicitly tackles tensions between groups in Papua by showing unity in terms of one soul. It is, like the other two histories, also an example of historical narrative building on the idea that there is a primordial substance. Foul outside forces have affected Papuan souls (see Suryawan 2012), creating imbalances that threaten the reunification that existed in the period of 'isolation and heathen power' (Flassy 1999: 9). The means of reunification proposed by the Constitution is the return to 'God's miracle' - Papuans as chosen people that would demand from Papuans dedication to their land's role in blessing the world.

Finally, all three narratives demonstrate that the producers of Papuan histories are a diverse crowd, including intellectuals, philosophers, bureaucrats, church ministers and local leaders. All the authors discussed above recognise that historiography is useful for current imaginations of sovereignty, development and identity, and can move people to action. Because of the concern and purpose of their narratives, they do not include doubt, hesitation or modesty but rather conviction about the paradigmatic truths they establish. The narratives confirm the kind of nationalism that seeks to identify pure forms of some putative national culture and flatten the erratic temporality of history. They 
From 'Stone-Age' to 'Real-Time'

turn the unpredictable succession of events into retroactive proof of a glorious predestination, and the coming of age of a perfect Papua that has a past that is so holy and remote that it seems exempt from the law of change.

\section{References}

Abdulgani, Roeslan 1964. Dari Sabang Sampai Merauke: Satu Nusa, Satu Bangsa! [From Sabang to Merauke: One Country, One People]. Djakarta: Departemen Penerangan R.I.

Alua, Agus A. 2002. 'Peringatan 41 Tahun. Tragedi kejahatan terhadap kemanusiaan di Tanah Papua dan Kemerdekaan Papua Barat'. Seri Pendidikan Politik Papua 6. Jayapura: Sekretariat Presidium Dewan Papua (PDP) dan Biro Penelitian STFT Fajar Timur.

Anderson, Benedict 1983. Imagined Communities: Reflections on the Origin and Spread of Nationalism. London: Verso Editions.

Asad, Talal 1993. Genealogies of Religion: Discipline and Reasons of Power in Christianity and Islam. Baltimore and London: The Johns Hopkins University Press.

Ballard, Chris 1997. 'It's the Land Stupid! The Moral Economy of Resource Ownership in Papua New Guinea'. In Larmour, Peter (ed.), The Governance of Common Property in the Pacific Region. Canberra: National Centre for Development Studies, 47-65.

Ballard, Chris 2014. 'Oceanic Historicities'. The Contemporary Pacific 26(1): 96124.

Chauvel, Richard 2005. Constructing Papuan Nationalism: History, Ethnicity, and Adaptation. Policy Studies 14. Washington, D.C.: East-West Center Washington.

Connerton, Paul 1989. How Societies Remember. Cambridge: Cambridge University Press.

Dening, Greg 1991. 'A Poetic for Histories: Transformations that Present the Past'. In Biersack, Aletta (ed.), Clio in Oceania: Towards a Historical Anthropology. Washington DC: Smithsonian Institution Press, 347-380.

Djopari, John R.G. 1993. Pemberontakan Organisasi Papua Merdeka. Second Edition. Jakarta: Penerbit PT Grasindo Gramedia Widiasarana. 
Drooglever, Pieter 2005. Een Daad van Vrije Keuze: De Papoea's van Westelijk Nieuw-Guinea en de Grenzen van het Zelfbeschikkingsrecht. Amsterdam: Boom.

Ferguson, James 2006. Global Shadows: Africa in the Neoliberal World. Durham: Duke University Press.

Fisher, Daniel and Timmer, Jaap 2013. 'Becoming Like The State: Ethnographic Perspectives On The State And Indigenous Sovereignty In Oceania'. Oceania 83(3): 153-157.

Flassy, Don A.L. 1985. Brendie Ceritra Rakyat (folktales), Toror, Doberai (Bird's Head), Irian Jaya. Penulisan, Seri, Jaya, Irian and Mansoben, J.R. (eds). Sorong: Studigrup Etnografi Irian Jaya, Dewan Kesenian Irian Jaya.

Flassy, Don A.L. 1999. Basic Guidelines, State of West Papua: Papua-Melanesia Threefold Logic, Basic Ideology, General Governance, Constitution of West Papua. Port Numbay (Jayapura): Fajar Melanesia.

Flassy, Don A.L. 2002. Toror: A Name Beyond Language and Culture Fusion. Jakarta: Balai Pustaka.

Gash, Noel and Whittaker, June 1975. A Pictorial History of New Guinea. Brisbane and Bathurst: Robert Brown and Associates.

Giay, Benny 1995. Zakheus Pakage and His Communities: Indigenous Religious Discourse, Socio-political Resistance, and Ethnohistory of the Me of Irian Jaya. PhD Thesis, Vrije Universiteit, Amsterdam. Amsterdam: VU University Press.

Giay, Benny 2000. Menuju Papua Baru: Beberapa pokok pikiran sekitar Emansipasi Orang Papua. Jayapura: Deiyai and Els-ham Papua.

Giay, Benny 2006. Peristiwa Penculikan dan Pembunuhan Theys H Eluay 10 November 2001. Jayapura: Deijay/Els-ham Papua.

Halbwachs, Maurice 1992 [1941/1952]. On Collective Memory. Edited and translated from the French by Lewis A. Coser. Chicago and London: The University Chicago Press.

Hau'ofa, Epeli 2000. 'Epilogue: Pasts to Remember'. In Borofsky, Robert (ed.), Remembrance of Pacific Pasts: An Invitation to Remake History. Honolulu: University of Hawai'i Press, 453-471.

Hendel, Ronald 2013. The Book of Genesis: A Biography. Princeton: Princeton University Press.

Hirsch, Eric and Stewart, Charles 2005. 'Introduction: Ethnographies of Historicity'. History and Anthropology 16(3): 261-274. 
From 'Stone-Age' to 'Real-Time'

Holton, George and Read, Kenneth H. 1971. The Human Aviary: A Pictorial Discovery of New Guinea. New York: Charles Scribner's Sons.

Ingold, Tim 2000. 'Ancestry, Generation, Substance, Memory, Land'. In Tim Ingold, The Perception of the Environment: Essays on Livelihood, Dwelling and Skill. Oxon and New York: Routledge, 132-151.

Jackson, Michael 1998. Minima Ethnographica: Intersubjectivity and the Anthropological Project. Chicago and London: The University of Chicago Press.

Kamma, Freerk C. 1947/48. 'De Verhouding tussen Tidore en de Papoese Eilanden in Legende en Historie, II'. Indonesië 1: 536-559.

Kamma, Freerk C. 1976. Dit Wonderlijke werk: Het Probleem van de Communicatie tussen Oost en West Gebaseerd op de Ervarigen in het Zendingswerk op Nieuw-Guinea (Irian Jaya) 1855-1972, Een Socio-missiologische Benadering. Oegstgeest: Raad voor de Zending der Ned. Hervormde Kerk.

Kamma, Freerk C., and Kooijman, Simon 1973. Romawa Forja, Child of the Fire: Iron Working and the Role of Iron in West New Guinea (West Irian). Leiden: E.J. Brill.

Kondjol, Zakarias L. 1996. Riwayat Kedatangnya Suku Onim Anggiluly Kondjol. Typescript, held in the collection of the author.

Karoba, Sem, Hans L. Gebze dkk. 2002. Papua Menggugat (11 November 2001, Hari Wafatnya Ondofolo Dortheys Hiyo Eluay). Yogyakarta: The West Papuan Community, Alliance of Papuan Students, The Koteka Tribal Assembly and Ndugu Ndugu Research and Publications.

Kirksey, Eben 2012. Freedom in Entangled Worlds: West Papua and the Architecture of Global Power. Durham and London: Duke University Press.

Koentjaraningrat and Bachtiar, Harsja W. 1963. Penduduk Irian Barat. Proyek Penelitian Universitas Indonesia 102. Jakarta: PT Penerbitan Universitas.

Leach, James 2003. Creative Land: Place and Procreation on the Rai Coast of Papua New Guinea. New York and Oxford: Berghahn.

Lincoln, Bruce 1989. Discourse and the Construction of Society: Comparative Studies of Myth, Ritual, and Classification. New York and Oxford: Oxford University Press.

Lotgering, F.K. 1940. Memorie van Overgave van de Onderafdeling Inanwatan over de periode 13 juni 1938 to 23 juli 1940. Typescript held in the Colonial Archives in The Hague (MMK 478). 
Maniagasi, Frans 2001. Masa Depan Papua: Merdeka, Otonomi Khusus dan Dialog. Jakarta: Millennium Publisher.

Miedema, Jelle, Odé, Cecilia, Dam, Rien A. C. and Baak, Connie (eds) 1998. Perspectives on the Bird's Head of Irian Jaya, Indonesia: Proceedings of the Conference, Leiden, 13-17 October 1997. Amsterdam: Editions Rodopi.

Ondawame, Otto 2009. One People, One Soul: West Papuan Nationalism and the Organisasi Papua Merdeka. Belair, SA: Crawford House.

Onim, Jusuf 1988. Soteriologi Agama Suku Tehit: Suatu Upaya Pemahaman terhadap Konsepsi Pemikiran Agamani tentang Tuhan dan Soteriologi menurut Agama Suku Tehit dalam Perjumpaannya dengan Agama Kristen di daerah Teminabuan, Kabupaten Sorong. Unpublished MA thesis, Sekolah Tinggi Theologia, Jakarta.

Onim, Jusuf 1998. A Regional History of Desa Wersar (in the Sub-district of Teminabuan) on the South Coast of the Bird's Head in Irian Jaya Indonesia. Unpublished Manuscript.

Pigay, Decki Natalis 2000. Evolusi nasionalisme dan sejarah konflik politik di Papua (Sebelum, Saat dan Sesudah Integrasi). Jakarta: Pustaka Sinar Harapan.

Raweyai, Yorrys Th. 2002. Mengapa Papua Ingin Merdeka. Jayapura: Presidium Dewan Papua.

Reid, Anthony 1979. 'The National Quest for an Indonesian Past'. In Reid, Anthony and Marr, David (eds), Perceptions of the Past in Southeast Asia. Southeast Asia Publication Series 4. Singapore: Heinemann Educational Books (Asia), 281-298.

Rutherford, Danilyn 2012. Laughing at Leviathan: Sovereignty and Audience in West Papua. Chicago and London: The University of Chicago Press.

Saltford, John 2002. Anatomy of a Betrayal: The United Nations and the Indonesian Takeover of West Papua, 1962-1969. London: Routledge Curzon.

Scott, James 2009. The Art of Not Being Governed: An Anarchist History of Upland Southeast Asia. New Haven and London: Yale University Press.

Scott, James 2012. Two Cheers for Anarchism: Six Pieces on Autonomy, Dignity, and Meaningful Work and Play. Princeton and Oxford: Princeton University Press.

Smith, Anthony D. 2003. Chosen Peoples: Sacred Sources of National Identity. Oxford: Oxford University Press. 
From 'Stone-Age' to 'Real-Time'

Suryawan, I Ngurah 2012. Jiwa yang Patah [Broken Soul]. Manokwari and Yogyakarta: Pusbadaya Universitas Negeri Papua and Kepel Press.

Timmer, Jaap 2000. Living with Intricate Futures: Order and Confusion in Imyan Worlds, Irian Jaya, Indonesia. Nijmegen: Centre for Pacific and Asian Studies, University of Nijmegen.

Timmer, Jaap 2005. 'Review of Dirk Vlasblom, Papoea: Een Geschiedenis (2004)'. Journal of Pacific History 40(1): 117-119.

Timmer, Jaap 2007a. 'Erring Decentralisation and Elite Politics in Papua'. In Nordholt, Henk Schulte and van Klinken, Gerry (eds), Renegotiating Boundaries: Local Politics in Post-Suharto Indonesia. Leiden: KITLV Press, 459-482.

Timmer, Jaap 2007b. 'A Brief Social and Political History of Papua, 1962-2004'. In Marshall, A.J. and Beehler, B.M. (eds), The Ecology of Papua. The Ecology of Indonesia Series Volume VI. Singapore: Periplus Editions, 1098-1123.

Timmer, Jaap 2013. 'The Threefold Logic of Papua-Melanesia: Constitutionwriting in the Margins of the Indonesian Nation-State'. Oceania 83(3): 158174.

van den Broek, Theo and Szalay, Alexandra 2001. 'Raising the Morning Star: Six Months in the Developing Independence Movement in West Papua'. Journal of Pacific History 36(1): 77-91.

van Kampen, Anthony 1967. Het Land dat God Vergat. Hilversum: C. de Boer jr.

Vlasblom, Dirk 2004. Papoea: Een Geschiedenis. Amsterdam: Mets and Schilt.

Wanane, Teddy K.E. 1991. Makna Kain Timur dalam Kehidupan Masyarakat Tehit di Daerah Kepala Burung. MA Thesis, Fakultas Ilmu Sosial dan Ilmu Politik, Universitas Cenderawasih, Jayapura.

White, Hayden 1987. The Content of the Form: Narrative Discourse and Historical Representation. Baltimore: The Johns Hopkins University Press.

Young, Michael W. 1997. ‘Commemorating Missionary Heroes: Local Christianity and Narratives of Nationalism'. In Otto, Ton and Thomas, Nicholas (eds), Narratives of Nation in the South Pacific. Amsterdam: Harwood Academic Publishers, 91-132. 
This text is taken from From 'Stone-Age' to 'Real-Time': Exploring Papuan Temporalities, Mobilities and Religiosities, edited by Martin Slama and Jenny Munro, published 2015 by ANU Press, The Australian National University, Canberra, Australia. 